\title{
Mycobacterium avium Paratuberculosis (MAP) and Cytomegalovirus (CMV) Are Frequently Detected in the Saliva of Patients Recently Diagnosed with Crohn Disease (CD) Whereas Oral Propionibacterium Acnes (PA) or Methylacetate (MA) in Their Breath Is Rare
}

\author{
Donatini Bruno, Le Blaye Isabelle \\ Medicine Information Formation, Cormontreuil, France \\ Email: donatini@orange.fr
}

Received 22 October 2015; accepted 11 December 2015; published 18 December 2015

\begin{abstract}
We investigated the presence of MAP, CMV, or Epstein-Barr virus (EBV) in the saliva of patients presenting with periodontal disease, gingivitis or oral aphthosis. We also measured methylacetate in their breath and looked for the presence of PA on their tongue. All patients were prospectively enrolled into a two-year cohort study. We compared the group presenting with CD versus the group without CD. 167 patients were enrolled. 24 patients presented with CD. CMV and MAP were found concomitantly in $67 \%$ of CD patients (17 patients) whereas only 1 patient $(<0.1 \% ; p<0.001)$ has these infectious agents in the comparative group. PA was rare in CD $(25 \%$ versus $70.6 \%$; $p<$ $0.001)$. MA was low, especially with an empty stomach $(0.59 \mathrm{ppm}+/-1.45$ versus $5.14 \mathrm{ppm}+/-$ 8.97; $p<0.001$ ). It was concluded that the association MAP + CMV was frequently found in oral lesions of CD at an early stage. Detection of PA, MAP and CMV, as well as breath test could be easily performed and may participate to the early diagnosis of $C D$.
\end{abstract}

\section{Keywords}

Mycobacterium avium, Cytomegalovirus, Crohn, Propionibacterium, VOC

\section{Introduction}

MAP [1]-[11], CMV or EBV [12]-[18] has been reported in CD. Early oral manifestations are frequent in CD [19]-[25], especially in young patients [26]-[35]. The ability of physicians to recognize Crohn's oral lesions is

How to cite this paper: Bruno, D. and Isabelle, L.B. (2015) Mycobacterium avium Paratuberculosis (MAP) and Cytomegalovirus (CMV) Are Frequently Detected in the Saliva of Patient Srecently Diagnosed with Crohn Disease (CD) Whereas Oral Propionibacterium Acnes (PA) or Methylacetate (MA) in Their Breath Is Rare. Journal of Biosciences and Medicines, 3, 13-18. http://dx.doi.org/10.4236/jbm.2015.312003 
poor [30] and the adequate diagnosis could suffer undesirable delays. We investigated whether MAP, CMV or EBV is present in early oral CD. In addition we investigated whether the oral microbiota was altered. PA was selected as a marker of the oral anaerobic flora in CD [36]. The gut microbiota which is altered in CD [37], was investigated by a breath test with the measure of methylacetate, a derivative of methaneknown to be decreased in $\mathrm{CD}$ [38] [39].

\section{Methods}

All patients consulting a private gastroenterologist and presenting with oral lesions (periodontal disease, gingivitis or oral aphthosis) were prospectively enrolled into a two-year cohort study. No patient had previously received any immunosuppressive agent. Only patients without Helicobacter pylori were considered (confirmed by gastro-duodenal biopsies or breath test: Helikit ${ }^{\circledR}$ ) in order to avoid a bias between CD and not-CD group.

Saliva was collected with swabs. Polymerase Chain Reaction (PCR) was run for MAP, CMV and EBV (Amplix ${ }^{\circledR}$ from Alldiag ${ }^{\circledR}$; reagents: Bioneer ${ }^{\circledR}$ and Adiavet ${ }^{\circledR}$ ) in a central laboratory.

The percentages of patients with CD (confirmed by ileoscopy) infected with either MAP, CMV or EBVwere compared to the percentages of patients without CD.

PAon the tongue was identified by its specific fluorescence when exposed to black light (Wood lamp; wavelength 320 - $450 \mathrm{~nm}$; peak $365 \mathrm{~nm}$ ) [40].

Breath test was performed with an ambulatory device (MX6 from Gazdetect ${ }^{\circledR}$ France). Methylacetate was measured with an empty stomach and two hours after the intake of lactulose and fructose as previously described [41] [42].

Comparisons of percentages were performed with a Student's t-test and Yates correction.

\section{Results}

167 patients with oral lesions were enrolled. No patient had previously received any immunosuppressive agents. All patients were Helicobacter pylori negative. CD was diagnosed in 24 patients.

MAP alone was found in 4 patients with CD. CMV was found alone once in CD. EBV was never found alone in CD. The combination MAP + EBV + CMV was only found once.

The association MAP + CMV was found in 16 patients with active CD.

Only one patient without CD was found positive with MAP + CMV. This patient presented with isolated palatine aphtose which abated with acyclovir therapy. Results are detailed in Table 1.

PA was less frequently detected in CD (25\% versus 70.4\%; $p<0.001)$; see Table 2.

Patients with CD breathe out less methylacetate, especially with an empty stomach ( 0.59 ppm $+/-1.45$ versus 5.14 ppm +/- 8.97; $p<0.001$ ); see Table 3 .

Table 1. Description of the PCR results according to the diagnosis of CD.

\begin{tabular}{cccccccccc}
\hline & $\begin{array}{c}\text { Neither MAP, } \\
\text { CMV or EBV }\end{array}$ & MAP & EBV & CMV & MAP + EBV & MAP + CMV & MAP + EBV + CMV & CMV + EBV & Total \\
\hline CD & 2 & 4 & 0 & 1 & 0 & $16^{*}$ & 1 & 0 & 24 \\
Other diseases & 111 & 12 & 5 & 6 & 7 & $1^{*}$ & 0 & 1 & 143 \\
Total & 113 & 16 & 5 & 7 & 7 & 17 & 1 & 1 & 167 \\
${ }^{*} P<0.001$. & & & & & & &
\end{tabular}

Table 2. Detection of oral Propionibacterium acnes (PA) according to the diagnosis of CD.

\begin{tabular}{cccc}
\hline & PA detected & PA not detected & Total \\
\hline CD & $6^{*}$ & 18 & 24 \\
Other diseases & $101^{*}$ & 42 & 143 \\
Total & 107 & 60 & 167 \\
\hline
\end{tabular}

\footnotetext{
${ }^{*} P<0.001$.
} 
Table 3. Detection of methylacetate (MA) in breath test according to the diagnosis of CD (measures in ppm: parts per million).

\begin{tabular}{ccccc}
\hline & $\begin{array}{c}\text { MA in breath on an } \\
\text { empty stomach }\end{array}$ & $\begin{array}{c}\text { MA in breath, 2 hours after } \\
\text { lactulose and fructose intake }\end{array}$ & $\begin{array}{c}\text { Hydrogen in breath } \\
\text { on an empty stomach }\end{array}$ & $\begin{array}{c}\text { Hydrogen in breath, 2 hours after } \\
\text { lactulose and fructose intake }\end{array}$ \\
\hline CD & $0.59+/-1.45^{*}$ & $1.73+/-1.92$ & $4.63+/-9.99$ & $17.16+/-19.24$ \\
Other diseases & $5.14+/-8.97^{*}$ & $4.29+/-6.28$ & $4.54+/-7.96$ & $18.40+/-22.03$ \\
\hline
\end{tabular}

${ }^{*} P<0.001$.

\section{Discussion}

Oral lesions, including periodontitis, are frequently associated with CD [19]-[35], CMV or EBV infection [43]-[52].

MAP or CMV has been associated with CD. Whether these infections are opportunistic or may be involved in the development of CD is unknown. These infectious agents are rather considered as environmental modifying agents [6] [7].

This study shows that the association MAP + CMV is frequently found in the saliva of patients with recent active $\mathrm{CD}$, presenting with oral lesions and before any immunosuppressive therapy.

Detection modalities of MAP are still debated [4] [8] [11]. However, since MAP infections could be aggravated by immunosuppressive agents such as anti-TNF-alpha [53], attempts to detect chronic infectious agents should be performed before the use of these medications.

PA is less frequently found in CD. Having a better oral hygiene, patients with $\mathrm{CD}$, may imbalance their oral flora [54]. A decreased prevalence of PA, which belongs to cariogenic flora [55], is compatible with the "hygiene hypothesis" [56] [57] suggested in CD.

CD is associated with a low prevalence of Helicobacter pylori infection [58]. All patients infected with Helicobacter pylori were therefore excluded to avoid a potential bias when comparing the two groups.

Exhaled MA was very low is CD, especially on an empty stomach. Specific VOC (1-octene, 1-decene, (E)-2nonene) have excellent accuracy for predicting the presence of Inflammatory Bowel Diseases [37]. Methane is known to be decreased in CD [59].

This study confirms that CD is associated firstly with a high frequency of oral MAP + CMV infection, secondly with decreased oral PA and thirdly with MA decrease in exhaled breath. These detections may be performed with ambulatory inexpensive, non-invasive and easy-to-use devices.

Larger studies are necessary to confirm these preliminary results.

\section{References}

[1] Naser, S.A., Ghobrial, G., Romero, C. and Valentine, J.F. (2004) Culture of Mycobacterium avium Subspecies Paratuberculosis from the Blood of Patients with Crohn's Disease. Lancet, 364, 1039-1044. http://dx.doi.org/10.1016/S0140-6736(04)17058-X

[2] Pickup, R.W., Rhodes, G., Arnott, S., Sidi-Boumedine, K., Bull, T.J., Weightman, A., et al. (2005) Mycobacterium avium subsp. Paratuberculosis in the Catchment Area and Water of the River Taff in South Wales, United Kingdom, and Its Potential Relationship to Clustering of Crohn's Disease Cases in the City of Cardiff. Appl Environ Microbiol., 71, 2130-2139. http://dx.doi.org/10.1128/AEM.71.4.2130-2139.2005

[3] Scanu, A.M., Bull, T.J., Cannas, S., Sanderson, J.D., Sechi, L.A., Dettori, G., et al. (2007) Mycobacterium avium Subspecies Paratuberculosis Infection in Cases of Irritable Bowel Syndrome and Comparison with Crohn's Disease and Johne's Disease: Common Neural and Immune Pathogenicities. J Clin Microbiol., 45, 3883-3890. http://dx.doi.org/10.1128/JCM.01371-07

[4] Pierce, E.S. (2009) Where Are All the Mycobacterium avium Subspecies Paratuberculosis in Patients with Crohn's Disease? PLoSPathog., 5, e1000234. http://dx.doi.org/10.1371/journal.ppat.1000234

[5] Mendoza, J.L., San-Pedro, A., Culebras, E., Cíes, R., Taxonera, C., Lana, R., et al. (2010) High Prevalence of Viable Mycobacterium avium Subspecies Paratuberculosis in Crohn's Disease. World J Gastroenterol., 16, 4558-4563. http://dx.doi.org/10.3748/wjg.v16.i36.4558

[6] Sibartie, S., Scully, P., Keohane, J., O’Neill, S., O'Mahony, J., O’Hanlon, D., et al. (2010) Mycobacterium avium subsp. Paratuberculosis (MAP) as a Modifying Factor in Crohn's Disease. Inflamm Bowel Dis., 16, 296-304. http://dx.doi.org/10.1002/ibd.21052 
[7] Singh, A.V., Singh, S.V., Singh, P.K. and Sohal, J.S. (2010) Is Mycobacterium avium subsp. Paratuberculosis, the Cause of Johne's Disease in Animals, a Good Candidate for Crohn's Disease in Man? Indian J Gastroenterol., 29, 5358. http://dx.doi.org/10.1007/s12664-010-0019-y

[8] Tuci, A., Tonon, F., Castellani, L., Sartini, A., Roda, G., Marocchi, M., et al. (2011) Fecal Detection of Mycobacterium avium Paratuberculosis Using the IS900 DNA Sequence in Crohn's Disease and Ulcerative Colitis Patients and Healthy Subjects. Dig Dis Sci., 56, 2957-2962. http://dx.doi.org/10.1007/s10620-011-1699-6

[9] Over, K., Crandall, P.G., O’Bryan, C.A. and Ricke, S.C. (2011) Current Perspectives on Mycobacterium avium subsp. Paratuberculosis, Johne's Disease, and Crohn's Disease: A Review. Crit Rev Microbiol., 37, 141-156. http://dx.doi.org/10.3109/1040841X.2010.532480

[10] Rhodes, G., Richardson, H., Hermon-Taylor, J., Weightman, A., Higham, A. and Pickup, R. (2014) Mycobacterium avium Subspecies Paratuberculosis: Human Exposure through Environmental and Domestic Aerosols. Pathogens., 16, 577-595. http://dx.doi.org/10.3390/pathogens3030577

[11] Timms, V.J., Mitchell, H.M. and Neilan, B.A. (2015) Optimisation of DNA Extraction and Validation of PCR Assays to Detect Mycobacterium avium subsp. Paratuberculosis. J Microbiol Methods, 112, 99-103. http://dx.doi.org/10.1016/j.mimet.2015.03.016

[12] Nakase, H., Yoshino, T., Honzawa, Y. and Chiba, T. (2010) Low Prevalence of CMV Infection in Patients with Crohn's Disease in Comparison with Ulcerative Colitis: Effect of Different Immune Response on Prevalence of CMV infection. Dig Dis Sci., 55, 1498-1499. http://dx.doi.org/10.1007/s10620-010-1162-0

[13] Wagner, J., Sim, W.H., Lee, K.J. and Kirkwood, C.D. (2013) Current Knowledge and Systematic Review of Viruses Associated with Crohn's Disease. Rev Med Virol., 23, 145-171. http://dx.doi.org/10.1002/rmv.1720

[14] Ryan, J.L., Shen, Y.J., Morgan, D.R., Thorne, L.B., Kenney, S.C., Dominguez, R.L., et al. (2012) Epstein-Barr Virus Infection is Common in Inflamed Gastrointestinal Mucosa. Dig Dis Sci., 57, 1887-98. http://dx.doi.org/10.1007/s10620-012-2116-5

[15] Knösel, T., Schewe, C., Petersen, N., Dietel, M. and Petersen, I. (2009) Prevalence of Infectious Pathogens in Crohn's Disease. Pathol Res Pract., 205, 223-230. http://dx.doi.org/10.1016/j.prp.2008.04.018

[16] Van Kruiningen, H.J., Poulin, M., Garmendia, A.E., Desreumaux, P., Colombel, J.F., De Hertogh, G., et al. (2007) Search for Evidence of Recurring or Persistent Viruses in Crohn’s Disease. APMIS, 115, 962-968. http://dx.doi.org/10.1111/j.1600-0463.2007.apm_564.X

[17] Yanai, H., Shimizu, N., Nagasaki, S., Mitani, N. and Okita, K. (1999) Epstein-Barr Virus Infection of the Colon with Inflammatory Bowel Disease. Am J Gastroenterol., 94, 1582-1586. http://dx.doi.org/10.1111/j.1572-0241.1999.01148.x

[18] Wakefield, A.J., Fox, J.D., Sawyerr, A.M., Taylor, J.E., Sweenie, C.H., Smith, M., et al. (1992) Detection of Herpesvirus DNA in the Large Intestine of Patients with Ulcerative Colitis and Crohn's Disease Using the Nested Polymerase Chain Reaction. J Med Virol., 38, 183-190. http://dx.doi.org/10.1002/jmv.1890380306

[19] Lankarani, K.B., Sivandzadeh, G.R. and Hassanpour, S. (2013) Oral Manifestation in Inflammatory Bowel Disease: A Review. World J Gastroenterol., 19, 8571-9. http://dx.doi.org/10.3748/wjg.v19.i46.8571

[20] Padmavathi, B., Sharma, S., Astekar, M., Rajan, Y. and Sowmya, G. (2014) Oral Crohn’s Disease. J Oral MaxillofacPathol.,48, S139-S142.

[21] Boryczka, G., Waluga, M., Budzyńska, A., Kajor, M. and Hartleb, M. (2015) Severe Viral Oesophagitis, Pharyngitis, and Stomatitis as Antecedents of Ileocecal Crohn's Disease. Prz Gastroenterol., 10, 47-50. http://dx.doi.org/10.5114/pg.2014.47495

[22] Nagpal, S., Acharya, A.B. and Thakur, S.L. (2012) Periodontal Disease and Anemias Associated with Crohn’s Disease. A Case Report. $N$ Y State Dent J., 78, 47-50.

[23] Michailidou, E., Arvanitidou, S., Lombardi, T., Kolokotronis, A., Antoniades, D. and Samson, J. (2009) Oral lesions leading to the diagnosis of Crohn disease: report on 5 patients. Quintessence Int., 40, 581-8.

[24] Ojha, J., Cohen, D.M., Islam, N.M., Stewart, C.M., Katz, J. and Bhattacharyya, I. (2007) Gingival Involvement in Crohn Disease. J Am Dent Assoc., 138, 1574-1581. http://dx.doi.org/10.14219/jada.archive.2007.0106

[25] Plauth, M., Jenss, H. and Meyle, J. (1991) Oral Manifestations of Crohn’s Disease. An Analysis of 79 Cases. J ClinGastroenterol., 13, 29-37. http://dx.doi.org/10.1097/00004836-199102000-00008

[26] Law, S.T. and Li, K.K. (2013) Age-Related Differences in the Clinical Course of Crohns Disease in an Asian Population: A Retrospective Cohort Review. Indian Pediatr., 50, 1148-1152. http://dx.doi.org/10.1007/s13312-013-0301-z

[27] Litsas, G. (2011) Crohn’s Disease of the Mouth: Report of a Case. Eur J Paediatr Dent., 12, 198-200.

[28] Lemberg, D.A. and Day, A.S. (2015) Crohn Disease and Ulcerative Colitis in Children: An Update for 2014. J Paediatr Child Health, 51, 266-270. http://dx.doi.org/10.1111/jpc.12685 
[29] William, T., Marsch, W.C., Schmidt, F. and Kreft, B. (2007) Early oral Presentation of Crohn's Disease. J DtschDermatolGes., 5, 678-679. http://dx.doi.org/10.1111/j.1610-0387.2007.06429.x

[30] Ganesh, R., Suresh, N., Ezhilarasi, S., Rajajee, S. and Sathiyasekaran, M. (2006) Crohn’s Disease Presenting as Palatal Ulcer. Indian J Pediatr., 73, 229-231. http://dx.doi.org/10.1007/bf02825488

[31] Harty, S., Fleming, P., Rowland, M., Crushell, E., McDermott, M., Drumm, B. and Bourke, B. (2005) A Prospective Study of the Oral Manifestations of Crohn’s Disease. Clin Gastroenterol Hepatol., 3, 886-91. http://dx.doi.org/10.1016/S1542-3565(05)00424-6

[32] Sigusch, B.W. (2004) Periodontitis as Manifestation of Crohn’s Disease in Primary Dentition: A Case Report. J Dent Child (Chic), 71, 193-196.

[33] Pittock, S., Drumm, B., Fleming, P., McDermott, M., Imrie, C., Flint, S., et al. (2001) The Oral Cavity in Crohn’s Disease. J Pediatr., 138, 767-771. http://dx.doi.org/10.1067/mpd.2001.113008

[34] Williams, A.J., Wray, D. and Ferguson, A. (1991) The Clinical Entity of Orofacial Crohn’s Disease. Q J Med., 79, 451-458.

[35] Coenen, C., Börsch, G., Müller, K.M. and Fabry, H. (1988) Oral Inflammatory Changes as an Initial Manifestation of Crohn's Disease Antedating Abdominal Diagnosis. Report of a Case. Dis Colon Rectum, 31, 548-552. http://dx.doi.org/10.1007/BF02553730

[36] Beeken, W.L. and Kanich, R.E. (1973) Microbial Flora of the Upper Small Bowel in Crohn’s Disease. Gastroenterology, 65, 390-397.

[37] Patel, N., Alkhouri, N., Eng, K., Cikach, F., Mahajan, L., Yan, C., et al. (2014) Metabolomic Analysis of Breath Volatile Organic Compounds Reveals Unique Breath Prints in Children with Inflammatory Bowel Disease: A Pilot Study. Aliment Pharmacol Ther., 40, 498-507. http://dx.doi.org/10.1111/apt.12861

[38] Rana, S.V., Sharma, S., Malik, A., Kaur, J., Prasad, K.K., Sinha, S.K., et al. (2013) Small Intestinal Bacterial Overgrowth and Orocecal Transit Time in Patients of Inflammatory Bowel Disease. Dig Dis Sci., 58, 2594-2598. http://dx.doi.org/10.1007/s10620-013-2694-x

[39] Pimentel, M., Mayer, A.G., Park, S., Chow, E.J., Hasan, A. and Kong, Y. (2003) Methane Production during Lactulose Breath Test Is Associated with Gastrointestinal Disease Presentation. Dig Dis Sci., 48, 86-92. http://dx.doi.org/10.1023/A:1021738515885

[40] Shu, M., Kuo, S., Wang, Y., Jiang, Y., Liu, Y.T., Gallo, R.L., et al. (2013). Porphyrin Metabolisms in Human Skin Commensal Propionibacterium acnes Bacteria: Potential Application to Monitor Human Radiation Risk. CM.Curr Med Chem., 20, 562-568. http://dx.doi.org/10.2174/0929867311320040007

[41] Donatini, B. and Le Blaye, I. (2015) A Prospective Cohort of 263 Patients with Irritable Bowel Syndrome (IBS) Followed One Year and Treated with Laetiporus sulphureus Plus Very Small Amounts of Essentials Oils. 8th International Medicinal Mushroom Conference (IMMC8), Manizales, 25 August 2015, Abstract.

[42] Donatini, B. and Le Blaye, I. (2015) Methylacetate Increase after a Lactulose Breath Test May Help to Detect Active EBV and/or HPV Infection. 26th International Congress on Anti-Cancer Treatment (ICACT), Paris, 3 February2015, Abstract.

[43] Pedersen, A. and Hornsleth, A. (1993) Recurrentaphthous Ulceration: A Possible Clinical Manifestation of Reactivation of Varicella Zoster or Cytomegalovirus Infection. J Oral Pathol Med., 22, 64-68. http://dx.doi.org/10.1111/j.1600-0714.1993.tb00045.X

[44] Kato, A., Imai, K., Ochiai, K. and Ogata, Y. (2015) Prevalence and Quantitative Analysis of Epstein-Barr Virus DNA and Porphyromonas gingivalis Associated with Japanese Chronic Periodontitis Patients. Clin Oral Investig., 19, 1605-1610. http://dx.doi.org/10.1007/s00784-014-1387-y

[45] Vincent-Bugnas, S., Vitale, S., Mouline, C.C., Khaali, W., Charbit, Y., Mahler, P., et al. (2013) EBV Infection Is Common in Gingival Epithelial Cells of the Periodontium and Worsens during Chronic Periodontitis. PLoS One, 8, e80336. http://dx.doi.org/10.1371/journal.pone.0080336

[46] Ozbek, S.M., Ozbek, A. and Yavuz, M.S. (2013) Detection of Human Cytomegalovirus and Epstein-Barr Virus in Symptomatic and Asymptomatic Apical Periodontitis Lesions by Real-Time PCR. Med Oral Patol Oral Cir Bucal., 18, e811-e816. http://dx.doi.org/10.4317/medoral.18905

[47] Sharma, R., Padmalatha, O., Kaarthikeyan, G., Jayakumar, N.D., Varghese, S. and Sherif, K. (2012) Comparative Analysis of Presence of Cytomegalovirus (CMV) and Epstein Barr virus -1 (EBV-1) in Cases of Chronic Periodontitis and Aggressive Periodontitis with Controls. Indian J Dent Res., 23, 454-458. http://dx.doi.org/10.4103/0970-9290.104948

[48] Chalabi, M., Rezaie, F., Moghim, S., Mogharehabed, A., Rezaei, M. and Mehraban, B. (2010) Periodontopathic Bacteria and Herpesviruses in Chronic Periodontitis. Mol Oral Microbiol., 25, 236-240.

http://dx.doi.org/10.4103/0970-9290.104948 
[49] Imbronito, A.V., Okuda, O.S., Maria de Freitas, N., Moreira Lotufo, R.F. and Nunes, F.D. (2008) Detection of Herpesviruses and Periodontal Pathogens in Subgingival Plaque of Patients with Chronic Periodontitis, Generalized Aggressive Periodontitis, or Gingivitis. J Periodontol.,79, 2313-2321. http://dx.doi.org/10.1902/jop.2008.070388

[50] Watanabe, S.A., Correia-Silva, J. de F., Horta, M.C., Costa, J.E. and Gomez, R.S. (2007) EBV-1 and HCMV in Aggressive Periodontitis in Brazilian Patients. Braz Oral Res., 21, 336-341. http://dx.doi.org/10.1590/S1806-83242007000400010

[51] Wu, Y.M., Yan, J., Ojcius, D.M., Chen, L.L., Gu, Z.Y. and Pan, J.P. (2007) Correlation between Infections with Different Genotypes of Human Cytomegalovirus and Epstein-Barr Virus in Subgingival Samples and Periodontal Status of Patients. J Clin Microbiol., 45, 3665-3670. http://dx.doi.org/10.1128/JCM.00374-07

[52] Saygun, I., Yapar, M., Ozdemir, A., Kubar, A. and Slots, J. (2004) Human Cytomegalovirus and Epstein-Barr Virus Type 1 in Periodontal Abscesses. Oral Microbiol Immunol., 19, 83-87. http://dx.doi.org/10.1046/j.0902-0055.2002.00118.x

[53] Yasui, K. (2014) Immunity against Mycobacterium tuberculosis and the Risk of Biologic Anti-TNF- $\alpha$ Reagents. Pediatr Rheumatol Online J., 12, 45. http://dx.doi.org/10.1186/1546-0096-12-45

[54] Singhal, S., Dian, D., Keshavarzian, A., Fogg, L., Fields, J.Z. and Farhadi, A. (2011) The Role of Oral Hygiene in Inflammatory Bowel Disease. Dig Dis Sci., 56, 170-175. http://dx.doi.org/10.1007/s10620-010-1263-9

[55] Bizhang, M., Ellerbrock, B., Preza, D., Raab, W., Singh, P., Beikler, T., et al. (2011) Detection of Nine Microorganisms from the Initial Carious Root Lesions Using a TaqMan-Based Real-Time PCR. Oral Dis., 17, 642-652. http://dx.doi.org/10.1111/j.1601-0825.2011.01815.x

[56] López-Serrano, P., Pérez-Calle, J.L., Pérez-Fernández, M.T., Fernández-Font, J.M., Boixeda de Miguel, D. and Fernández-Rodríguez, C.M. (2010) Environmental Risk Factors in Inflammatory Bowel Diseases. Investigating the Hygiene Hypothesis: A Spanish Case-Control Study. Scand J Gastroenterol., 45, 1464-1471. http://dx.doi.org/10.3109/00365521.2010.510575

[57] Guarner, F., Bourdet-Sicard, R., Brandtzaeg, P., Gill, H.S., McGuirk, P., van Eden, W., et al. (2006) Mechanisms of Disease: The Hygiene Hypothesis Revisited. Nat Clin Pract Gastroenterol Hepatol., 3, 275-84. http://dx.doi.org/10.1038/ncpgasthep0471

[58] Roka, K., Roubani, A., Stefanaki, K., Panayotou, I., Roma, E. and Chouliaras, G. (2014) The Prevalence of HELICOBACTER pylori Gastritis in Newly Diagnosed Children with Inflammatory Bowel Disease. Helicobacter, 19, 400-405. http://dx.doi.org/10.1111/hel.12141

[59] Kurada, S., Alkhouri, N., Fiocchi, C., Dweik, R. and Rieder, F. (2015) Review Article: Breath analysis in Inflammatory Bowel Diseases. Aliment Pharmacol Ther., 41, 329-341. http://dx.doi.org/10.1111/apt.13050 